\title{
Praćenje protutijela HLA prije transplantacije bubrega Luminex tehnikom
}

\section{Pre-transplant monitoring of HLA antibodies performed by Luminex- based assays}

\author{
Nataša Katalinić ${ }^{1,2^{*}}$, Tajana Crnić Marčetić ${ }^{1}$, Sanja Balen ${ }^{1,2}$
}

${ }^{1}$ Klinički zavod za transfuzijsku medicinu, Klinički bolnički centar Rijeka, Rijeka, Hrvatska

${ }^{2}$ Medicinski fakultet Sveučilišta u Rijeci, Rijeka, Hrvatska

\section{*Dopisni autor:}

Dr. sc. Nataša Katalinić, dr. med. Laboratorij za tipizaciju tkiva, Klinički zavod za transfuzijsku medicinu, Klinički bolnički centar Rijeka, Tome Strižića 3, 51000 Rijeka E-mail: tipizacija@kbc-rijeka.hr

\begin{abstract}
Sažetak. Prisutnost protutijela HLA (engl. Human Leucocyte Antigen) u primatelja predstavlja jedan od najznačajnijih imunosnih čimbenika koji utječu na ishod transplantacije bubrega. Stoga test probira seruma na prisutnost protutijela HLA i određivanje njihove specifičnosti predstavlja iznimno važan dio imunogenetske obrade potencijalnog primatelja organa. Posljednjih desetljeća zlatni standard u ispitivanju senzibilizacije primatelja je metoda citotoksičnosti ovisne o komplementu (engl. Complement-dependent cytotoxicity; CDC), međutim, niska osjetljivost ove metode potaknula je razvoj novih tehnika, poput protočne citometrije i tehnika čvrste faze među kojima je Luminex tehnologijom postignuta najveća osjetljivost i specifičnost. U Laboratoriju za tipizaciju tkiva Rijeka probir seruma pacijenata provodi se usporedno metodom CDC i Luminex tehnikom, čije su osobitosti prikazane ovim radom. Uz mnoge prednosti, Luminex tehnika ima ograničenja koja interpretaciju rezultata testiranja čini složenom i zahtjevnom. Zbog toga se određivanje specifičnosti klinički značajnih protutijela HLA zasniva na rezultatima testiranja i metodom CDC i Luminex tehnikom. Uključuje brojne čimbenike koji zahtijevaju usku suradnju djelatnika laboratorija za tipizaciju tkiva i kliničara, a zasnivaju se na individualnoj procjeni imunosnog i kliničkog statusa svakog pacijenta. Uz brojne izazove, uvođenje Luminex tehnike u probir seruma pacijenata omogućilo je stjecanje novih spoznaja o važnosti i ulozi protutijela HLA u reakciji odbacivanja presatka, te donijelo važne promjene u kliničkoj transplantacijskoj medicini.
\end{abstract}

Ključne riječi: imunizacija; Luminex; protutijela; sustav HLA; testovi tkivne podudarnosti; transplantacija bubrega

Abstract. Human Leucocyte Antigen (HLA) alloimmunization is one of the most significant immune factors affecting the outcome of a kidney transplantation. Therefore, a sera screening and identification of antibody specificity are an extremely important part of the immunogenetic assessment of a potential organ recipient. In recent decades, the complement-dependent lymphocytotoxicity (CDC) assay has been the "gold standard" to detect and identify HLA antibodies. However, the low sensitivity of this method has encouraged the development of new techniques such as flow cytometry and solid phase techniques among which the highest sensitivity and specificity has been achieved with the Luminex technology. At the Tissue Typing Laboratory Rijeka, the screening of patients' sera is performed in parallel with the CDC method and the Luminex technique, the characteristics of which are presented in this paper. With many advantages, the Luminex technique has several limitations that make the interpretation of test results complex and demanding. Therefore, the determination of clinically relevant HLA antibodies is based on the test results of both, CDC and Luminex technique. It involves number of factors that require close collaboration between tissue typing laboratory staff and clinicians based on individual patient assessment. Despite many challenges, the introduction of the Luminex technique into the screening of recipients' serum has enabled to gain new insights into the importance and role of HLA antibodies in graft rejection and has brought some important changes in clinical transplant medicine.

Key words: antibodies; histocompatibility; human leukocyte antigens; immunization; kidney transplantation; Luminex 


\section{UVOD}

HLA aloimunizacija primatelja predstavlja jedan od najznačajnijih imunosnih čimbenika koji utječu na ishod transplantacije bubrega. Protutijela usmjerena na nepodudarne antigene HLA koji su izraženi na stanicama davatelja organa (engl. Donor-Specific Alloantibody; DSA) mogu uzrokovati različite oblike odbacivanja presatka, poremećaj funkcije i skraćeno vrijeme preživljavanja presađenog bubrega, te veću učestalost nuspojava imunosupresivne terapije slika 1). Imunizirani pacijenti duže čekaju na transplantaciju s obzirom na to da im je sužen izbor davatelja bubrega koji nemaju antigene neprihvatljivih specifičnosti ${ }^{1,2}$.

Protutijela se stvaraju kao posljedica izloženosti primatelja stranim antigenima HLA tijekom prethodnih transplantacija organa ili tkiva, trudnoća i/ ili transfuzija krvnih pripravaka, premda su dokazani i u osoba bez poznatog imunizirajućeg događa$\mathrm{ja}^{2,3}$. Mogu se otkriti nakon kontakta s ne-HLA antigenima mikroorganizama, proteina ili alergena koji su križno reaktivni s molekulama HLA-a. Uz infekciju, proupalni događaji poput operativnih zahvata ili traume izazivaju porast i titra i širine specifičnosti već stvorenih protutijela ${ }^{4-8}$.

Osnovni postupci kojima se dokazuje prisutnost protutijela HLA jesu probir seruma pacijenata (engl. screening) i križna reakcija između seruma primatelja i limfocita davatelja (engl. crossmatch; CM). Standardna, a ujedno i najstarija metoda kojom se izvode je metoda CDC ${ }^{9}$.

Screening seruma potencijalnih primatelja bubrega provodi se kroz redovite intervale, svaka tri mjeseca, te predstavlja jedan od najzahtjevnijih postupaka u laboratoriju za tipizaciju tkiva (LTT). Prisutnost i praćenje protutijela HLA metodom CDC-a izvodi se testiranjem seruma pacijenata $s$ panelom limfocita poznate tipizacije HLA, koji se u Rijeci sastoji od 50 stanica davatelja krvi. Sastav i učestalost antigena u panelu limfocita odraz je raspodjele antigena HLA-a u ispitivanoj populaciji potencijalnih davatelja organa. Pozitivne reakcije znače da se u serumu primatelja nalaze protutijela na određene antigene HLA, izražene na nekim (ili svim) limfocitima panela. Rezultat se označava kao postotak panel reaktivnih protutijela (engl. Panel Reactive Antibodies; \%PRA), kojim se procjenjuje udio potencijalnih davatelja organa s ko- jima bi primatelj mogao imati pozitivnu križnu reakciju. Analizom reakcija seruma pacijenata $i$ antigena HLA limfocita panela određuje se specifičnost protutijela, odnosno identificiraju se nepodudarni, neprihvatljivi antigeni (engl. Unacceptable Antigen Mismatches; UAM) ${ }^{10,11}$.

Mnoge studije, među kojima je najznačajnija Terasakijeva, dokazale su povezanost donor-specifičnih limfocitotoksičnih IgG protutijela u serumu primatelja s hiperakutnom reakcijom odbacivanja organa $^{12}$. Stoga se kao posljednji test provjere prisutnosti DSA-a prije transplantacije bubrega izvodi CM metodom CDC-a. Pozitivan rezultat dokaz je prisutnosti protutijela HLA usmjerenih prema antigenima HLA davatelja te predstavlja apsolutnu kontraindikaciju za transplantaciju bubrega.

HLA aloimunizacija primatelja predstavlja jedan od najznačajnijih imunosnih čimbenika koji utječu na ishod transplantacije bubrega. Stoga test probira seruma na prisutnost protutijela HLA i određivanje njihove specifičnosti predstavlja važan dio imunogenetske obrade potencijalnog primatelja organa. Uz standardnu metodu CDC-a razvile su se nove tehnike, među kojima je Luminex tehnikom postignuta najveća osjetljivost.

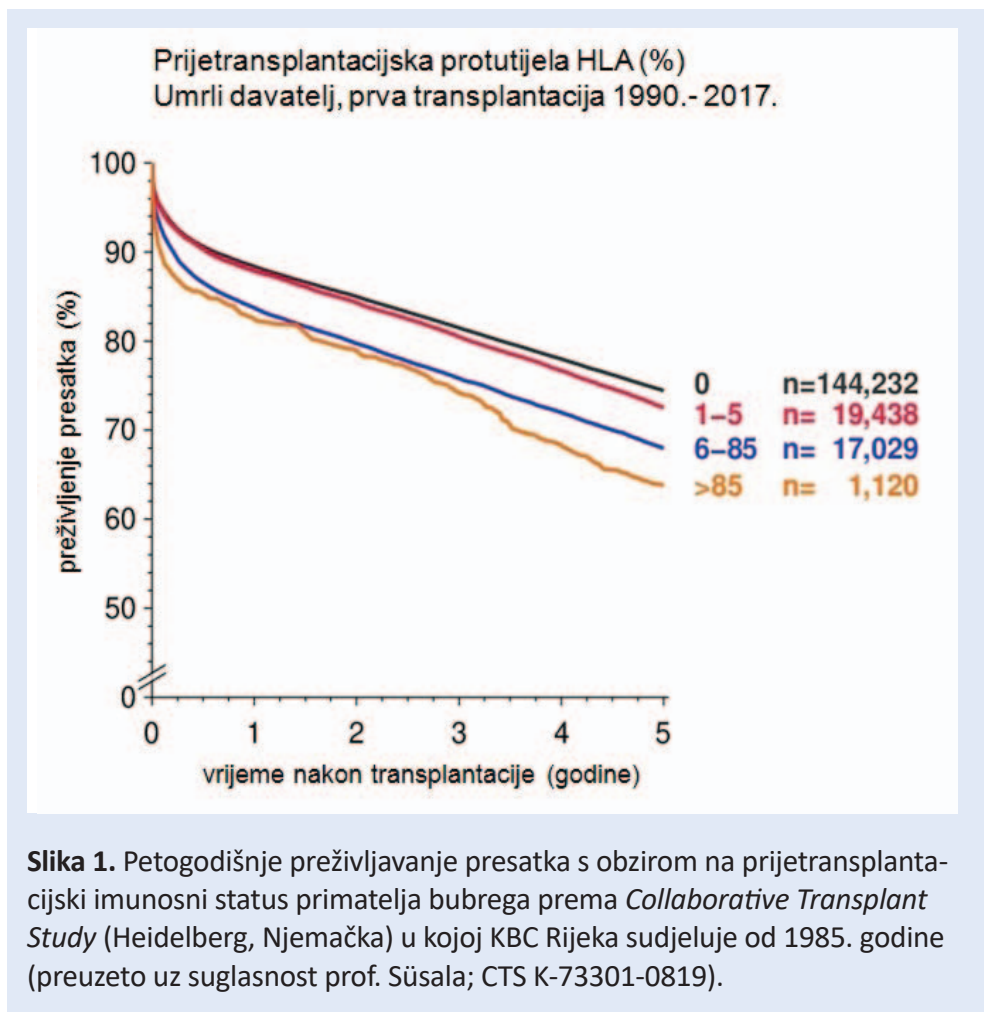




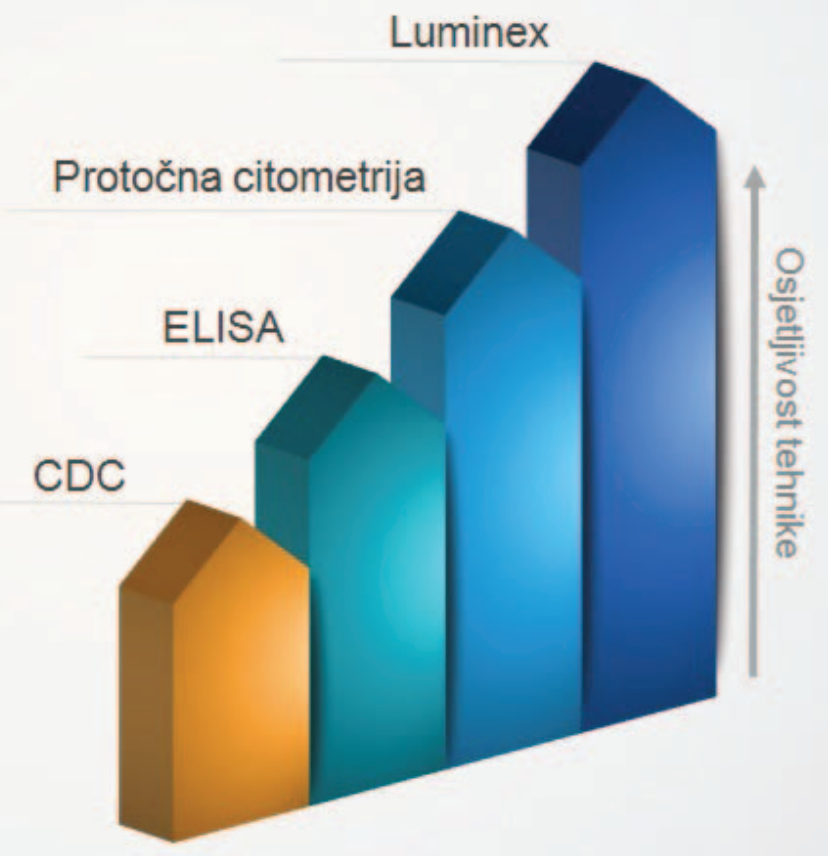

Slika 2. Razine osjetljivosti tehnika otkrivanja protutijela HLA.

Međutim, testovima CDC ne može se dokazati prisutnost protutijela HLA u niskom titru, što je potaknulo razvoj novih tehnika i metoda, poput protočne citometrije i tehnika čvrste faze (Enzyme Linked Immuno Sorbent Assay, Luminex $)^{13,14}$. Danas metoda zasnovana na Luminex tehnologiji predstavlja test najveće osjetljivosti i specifičnosti (slika 2). Zbog toga je LTT Rijeka uveo Luminex tehniku u screening seruma pacijenata 2012., kao komplementarni test dotad primjenjivanoj metodi CDC (tablica 1).
Testiranja u svrhu transplantacije organa mogu provoditi samo akreditirani laboratoriji koji rezultate prijavljuju Eurotransplantu (ETRL - Eurotransplant Reference Laboratory) ${ }^{15}$. U Republici Hrvatskoj su dva LTT-a, u Zagrebu i Rijeci, stekla akreditaciju Europskog društva za imunogenetiku (European Federation for Immunogenetics; EFI) koju uspješno obnavljaju već više od deset godina.

\section{OSNOVNI PRINCIP LUMINEX TEHNIKE}

Test se zasniva na principima protočne citometrije. Koriste se polistirenske mikrokuglice na koje su konjugirani pročišćeni glikoproteini (antigeni) HLA razreda I i/ili II ${ }^{16}$. Svaki test sadrži do 100 setova mikrokuglica unutar kojih se nalaze fluorokromi u različitim omjerima, dajući svakom setu jedinstveni spektralni signal.

Osnovni princip je da se nakon inkubacije mikrokuglica sa serumom pacijenata eventualno prisutna IgG protutijela HLA specifično vežu na komplementarne antigene konjugirane na mikrokuglice, dok se nevezana protutijela ispiru. Vezana protutijela HLA označavaju se dodatkom antihumanog IgG protutijela označenog fluorescentnom bojom phycoeritrinom (PE) (Slika 3).

Reakcije se očitavaju u Luminex fluorocitometru pomoću dvaju lasera. Crvenim laserom se pobuđuju fluorokromi u mikrokuglici i time se istovremeno identificira jedinstveni signal pojedinog seta mikrokuglica na kojima su konjugirani antigeni HLA određene specifičnosti. Zeleni laser pobuđuje fluorescentnu boju (PE) koja je vezana na

Tablica 1. Prikaz osnovnih razlika između metode CDC i Luminex tehnologije u otkrivanju protutijela HLA

\begin{tabular}{|l|c|c|}
\cline { 2 - 3 } \multicolumn{1}{c|}{} & \multicolumn{1}{c|}{ CDC metoda } & $\checkmark$ \\
\hline Dokazivanje protutijela HLA u niskom titru & $\checkmark$ & $\checkmark$ \\
\hline Određivanje specifičnosti protutijela HLA & $\begin{array}{c}\text { Ograničeno (visokoimunizirani } \\
\text { pacijenti) }\end{array}$ & $\begin{array}{c}\text { Modifikacija } \\
\text { (C1q, C3d testovi) }\end{array}$ \\
\hline Dokazivanje samo protutijela koja aktiviraju komplement & $\checkmark$ & $\checkmark$ \\
\hline Dokazivanje prisutnosti protutijela HLA razreda I & $\checkmark$ & $\checkmark$ \\
\hline Dokazivanje prisutnosti protutijela HLA razreda II & (odvajanje T i B limfocita) \\
\hline Određivanje protutijela HLA razreda IgM & Modifikacija & (DTT) \\
\hline Otkrivanje protutijela na rijetke alele & $\varnothing$ & Modifikacija \\
\hline CDC- citotoksičnost ovisna o komplementu, DTT - dithiothreitol, HLA - humani leukocitni antigen & $\checkmark$ \\
\hline
\end{tabular}




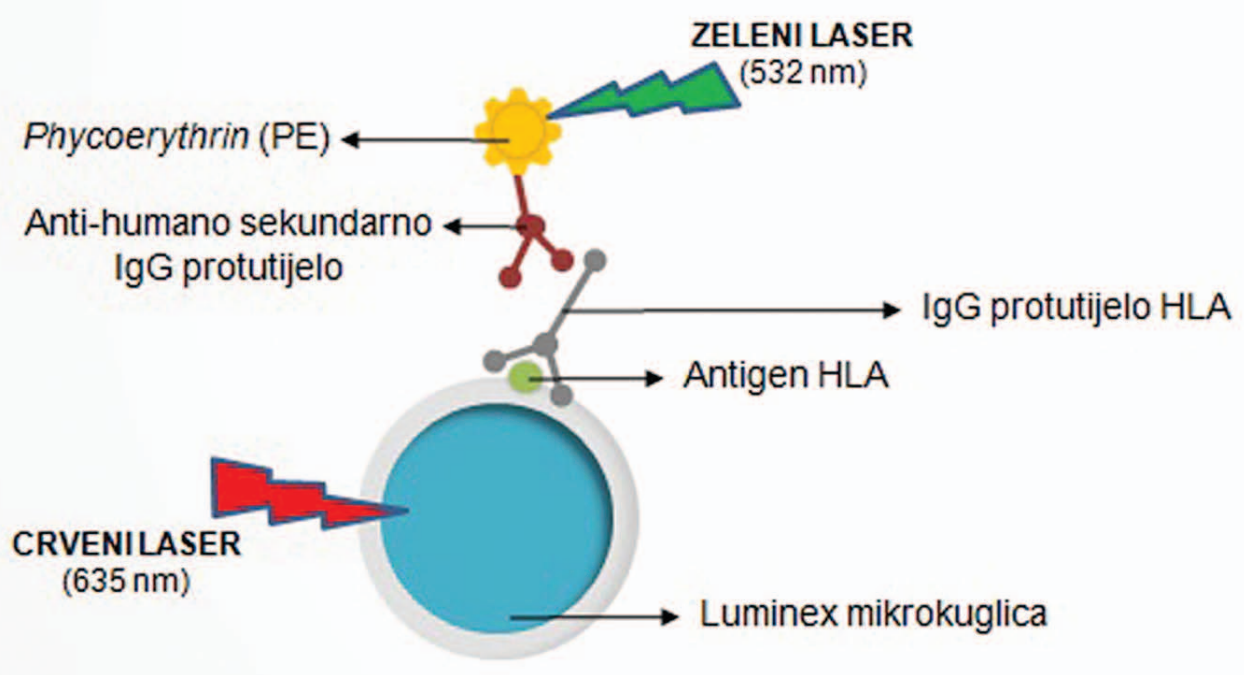

Slika 3. Shema osnovnog principa Luminex tehnike

sekundarno protutijelo imunokompleksa. Nakon mjerenja signala u aparatu, rezultati se obrađuju u kompjutorskom programu. Kombinacijom signala određuje se specifičnost protutijela u testiranom serumu, a razina fluorescencije izražava kao srednji intenzitet fluorescencije (engl. Mean Fluorescence Intensity; MFI) ${ }^{11,17}$.

Ispitivanje prisutnosti protutijela HLA u serumu pacijenata Luminex tehnikom moguće je provesti na tri razine. Prvom razinom provodi se kvalitativno testiranje u kojem se rezultat izražava kao pozitivan ili negativan. Time započinje screening seruma Luminex tehnikom u LTT-u Rijeka (LIFECODES LifeScreen Deluxe (LMX), Immucor GTI Diagnostics, Stanford, CT, SAD) (slika 4).

Druga razina daje informaciju o postotku panel reaktivnih protutijela HLA razreda I i II. Najvišu razinu predstavlja testiranje mikrokuglicama koje
Tissue typing laboratory Rijeka

Tome Strizica 3

51000 Rijeka, Croatia

Run Date: 01.10 .2018 LMX

\begin{tabular}{l|l|l}
\hline Sample ID: $000000 \mathrm{NC}$ & \\
Patient Name: $000000 \mathrm{NC}$ & \\
Accession: & & \\
Draw Date: & &
\end{tabular}

Comments: Sample ID: $000000 \mathrm{PC}$
Patient Name: $000000 \mathrm{PC}$ Accession: Draw Date:

Patient Name:

Accession:

Draw Date:

comments: Lot Number: 30057083005633 Expiration Date $\quad 07.15 .2018$

Comments:

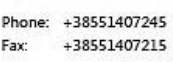

Phone: +38551407245

Fax: $\quad+38551407215$

Class I/II LMX Results

Batch ID: LMX300570810012018 SCRXII2017

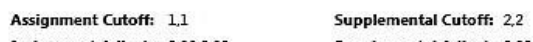

Assignment Adjust: $0.00,0.00 \quad$ Supplemental Adjust: $0.00,0.00$

Report By: Lab Supervisor

\begin{tabular}{|c|c|c|c|c|c|c|c|c|c|c|c|c|c|c|c|}
\hline & \multicolumn{8}{|c|}{ Class I Results } & \multicolumn{6}{|c|}{ Class II Results } & \multirow{2}{*}{$\begin{array}{l}\text { CONS } \\
\text { Pos } \mathrm{CH}\end{array}$} \\
\hline & $a-01$ & c1.02 & $a-03$ & a. 04 & $\mathrm{a}-05$ & a-06 & $a-07$ & Assignment & a1-01 & CII-02 & CII-03 & CII-04 & CII-05 & Assignment & \\
\hline Raw & 159 & 179 & 155 & 192 & 180 & 264 & 147 & & 267 & 230 & 216 & 181 & 161 & & 18784 \\
\hline & -201 & -1.74 & -155 & -1.24 & -1.79 & -1.98 & -1.59 & & -2.12 & -202 & -246 & -1.55 & -323 & & 137 \\
\hline Adj 2 & -273 & -2.13 & $-1,78$ & -1.87 & -245 & -288 & -1.95 & & -2.19 & -228 & -256 & -188 & -326 & & 151 \\
\hline $\mathrm{Adj} 3$ & -236 & -2.00 & -192 & -1.96 & -229 & -2.95 & -1.87 & & -2.65 & -2.62 & -3.06 & -199 & -323 & & 682 \\
\hline & 0 & 0 & 0 & 0 & 0 & 0 & 0 & Negative & 0 & 0 & 0 & 0 & 0 & Negative & \\
\hline
\end{tabular}

\begin{tabular}{|c|c|c|c|c|c|c|c|c|c|c|c|c|c|c|c|}
\hline Rasw & 13606 & 13209 & 16865 & 8959 & 17401 & 13120 & 15183 & & 15847 & 12126 & 20535 & 8944 & 3583 & & 20786 \\
\hline Adj 1 & 60.41 & 58.68 & 76.13 & 39.23 & 78.21 & 57,40 & 68.30 & & 69.99 & 52.96 & 91.92 & 38.92 & 12.33 & & 214 \\
\hline Adj 2 & 47.17 & 46.16 & 60.36 & 3041 & 61.53 & 4451 & 53.95 & & 55.39 & 41.61 & 72.92 & 30.42 & 9.09 & & 267 \\
\hline $\operatorname{Adj} 3$ & 28.05 & 27.49 & 35.83 & 1793 & 36.64 & 2621 & 32.12 & & 32.65 & 24.36 & 42.83 & 17.89 & 4.60 & & 444 \\
\hline Score & 3 & 3 & 3 & 3 & 3 & 3 & 3 & Positwe & 3 & 3 & 3 & 3 & 3 & Positive & \\
\hline
\end{tabular}

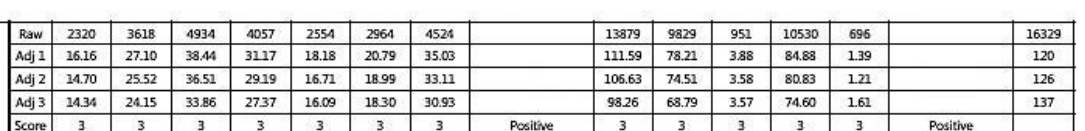

Slika 4. Pozitivan rezultat LIFECODES LifeScreen Deluxe (LMX) testa. Rezultat ispitivanog seruma određuje se evaluacijom reaktivnosti protutijela s mikrokuglicama, a konačni ishod testiranja izražava kao negativan ili pozitivan za prisutnost protutijela na molekule HLA razreda I i II. Uz svaki rezultat testiranog seruma prikazani su rezultati pozitivne (PC) i negativne (NC) kontrole. 


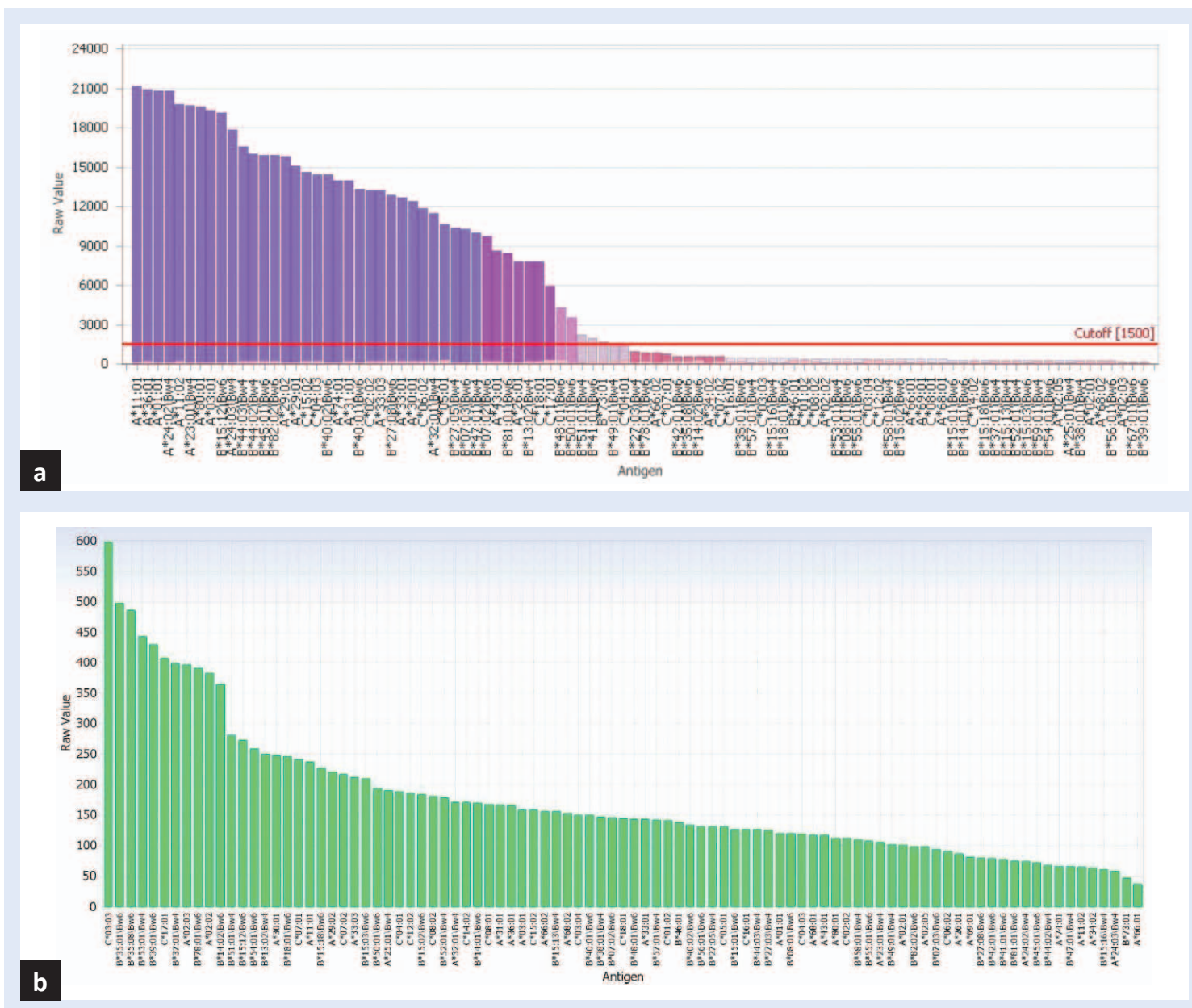

Slika 5. Prikaz rezultata testova Luminex LIFECODES Single Antigen (LSA I): a) pozitivan rezultat; b) negativan rezultat. Na apscisi su prikazane specifičnosti protutijela za HLA razred I, a na ordinati pripadajuća MFI vrijednost.

su obložene molekulama HLA iste (jedne) specifičnosti (engl. Single Antigen Bead; $S A B$ ). Time se omogućuje određivanje specifičnosti protutijela HLA. U LTT-u Rijeka se izvodi kao nastavak obrade pozitivnog rezultata LMX testa (Luminex Lifecodes Single Antigen; LSA I i/ili LSA II, Immucor GTI Diagnostics, Stanford, CT, SAD) (slika 5).

\section{INTERPRETACIJA REZULTATA LUMINEX}

\section{TESTOVA}

Luminex tehnika ima svoje prednosti i nedostatke koje je neophodno poznavati prilikom interpretacije rezultata. Najveća prednost ove tehnike je visoka osjetljivost i specifičnost $u$ ispitivanju prisutnosti protutijela HLA. Luminexom se mogu otkriti protutijela u niskom titru koja se drugim metodama ne mogu dokazati ${ }^{11}$.

Korištenjem odgovarajućih SAB testova dokazuju se protutijela na antigene razreda I (HLA-A, -B, -C) kao i svih osam lokusa razreda II (HLA-DRB1, -DRB3, -DRB4, -DRB5, -DQA, -DQB, -DPA, -DPB). Velika vrijednost ove tehnike je u određivanju specifičnosti protutijela HLA kod visokoimuniziranih pacijenata, što je vrlo teško, a često i nemoguće metodom $\mathrm{CDC}^{11}$. Također, mogu se otkriti protutijela na rijetke alele zahvaljujući širokom spektru antigena HLA na mikrokuglicama koje Luminex može razlikovati ${ }^{18}$.

Osnovni nedostatak Luminex tehnologije je u osnovi prevelika osjetljivost, te se otkrivaju protutijela u vrlo niskim koncentracijama kod kojih je dvojben klinički značaj u transplantaciji organa. Brojne studije dokazuju da su protutijela dokazana samo Luminex tehnologijom (ne i metodom $\mathrm{CDC}$ ) relativna, ali ne i apsolutna kontraindikacija za transplantaciju ${ }^{19}$.

Standardnim testovima nije moguće razlikovati komplement vezujuća IgG protutijela od ostalih 
koja ne aktiviraju komplement i nemaju klinički značaj. Tada je potrebno koristiti dodatne, posebno dizajnirane testove čija je učinkovitost još u fazi ispitivanja.

Osim toga, u SAB testovima koriste se rekombinantne, umjetno dobivene molekule HLA koje se konjugiraju na mikrokuglice. Sam postupak dobivanja i vezanja antigena može prouzročiti konformacijske promjene koje mogu dovesti do izlaganja kriptogenih epitopa (epitopi koji su u prirodnoj molekuli HLA zaštićeni od izlaganja protutijelima) ili gubitka strukture nativnih epitopa i time lažno pozitivnih, odnosno negativnih rezultata. Poznat je i prozonski učinak u kojem kod visokoimuniziranih pacijenata rezultat testiranja seruma može biti negativan ili slabo pozitivan, a nakon dilucije seruma visoko reaktivan ${ }^{10}$.

Lažno negativni rezultati mogu uzrokovati uzaludno slanje organa davatelja u centar potencijalnog primatelja, neočekivano pozitivan $\mathrm{CM}$, ili, u najgorem slučaju, transplantaciju imunološki nepodudarnog organa. Lažno pozitivan rezultat uzrokuje pogrešno određivanje antigena neprihvatljivih specifičnosti i još veće smanjenje izbora podudarnog davatelja imuniziranom pacijentu ${ }^{20}$. Jedna od najčešćih pogrešaka u interpretaciji rezultata je shvaćanje MFI vrijednosti kao titra protutijela. MFI vrijednost doista ovise o količini protutijela, ali i o afinitetu njihova vezanja na antigen, gustoći i raspodjeli antigena na kuglicama te strukturi denaturirane molekule HLA.

Također, granična (engl. cut-off) MFI vrijednost iznad koje se rezultati interpretiraju kao pozitivni nije standardizirana. Svaki laboratorij određuje vlastiti cut-off prema kontrolnim MFI vrijednostima te kliničkim iskustvima pripadajućeg transplantacijskog centra. Temeljem navedenog, u LTT-u Rijeka se specifičnosti protutijela s MFI vrijednostima većim od 1500 smatraju pozitivnim, međutim, interpretacija rezultata mora biti individualna neovisno o MFI vrijednostima. U našem centru se nepodudarni antigeni iz prethodnih transplantacija smatraju neprihvatljivima i u slučaju kada su DSA nižih MFI vrijednosti od cut-offa. Uz MFI vrijednosti neophodno je pratiti i reakciju protutijela na epitope, osobito kod visokoimuniziranih pacijenata i polispecifičnih seruma. Osim toga, cut-off ovisi o imunogeničnosti ciljne molekule, pa će kod protutijela na antigene
HLA-C biti viši nego u protutijela na većinu molekula lokusa HLA-B. Od iznimne važnosti je i podatak o imunizirajućim događajima te će kod pacijenata koji im nije bio izložen pozitivitet najvjerojatnije biti interpretiran kao lažni.

Protutijela otkrivena metodom CDC-a su apsolutna kontraindikacija za transplantaciju, dok se protutijela dokazana samo Luminex tehnikom danas smatraju relativnom kontraindikacijom. Prednosti i ograničenja Luminex tehnike čine interpretaciju rezultata testiranja složenom i zahtjevnom, pa je nužna dobra suradnja djelatnika laboratorija za tipizaciju tkiva i kliničara, temeljena na individualnom pristupu pacijentu.

\section{KLINIČKI ZNAČAJ PROTUTIJELA HLA} DOKAZANIH LUMINEX TEHNIKOM

Razvoj tehnika čvrste faze, a posebice uvođenje Luminex tehnike, donijelo je brojne promjene u kliničkoj transplantacijskoj medicini. Sve je učestalija primjena virtualnog PRA (engl. virtual PRA; VPRA) čije se određivanje pomoću računalnog programa zasniva na učestalosti antigena HLA u populaciji davatelja organa na koje primatelj ima stvorena protutijela, a ne na reaktivnosti seruma sa stanicama panela limfocita (\%PRA). Time se smanjuju razlike između laboratorija, prvenstveno u sastavu panela, te postiže ujednačenost i pouzdanost procjene stupnja imunizacije ${ }^{21}$.

Tehnike čvrste faze omogućile su i uvođenje virtualnog CM-a koji Eurotransplant već jednim dijelom i koristi u alokaciji organa. U Rijeci se, u neimuniziranih pacijenata koji zadovoljavaju uvjete određene EFI Standardima, transplantacija bubrega započinje ne čekajući rezultate CM-a. Time se postiže smanjenje vremena hladne ishemije, što je značajan čimbenik u preživljavanju presatka, naročito u slučajevima kada se organ šalje iz udaljenijih dijelova Europe.

Veliki napredak postignut je razvojem kompjutorskih programa kojima je cilj identifikacija nepodudarnih molekula HLA koje neće dovesti do stvaranja protutijela u primatelja organa (HLAMatchmaker, Predicted Indirectly ReCognizable HLA Epitopes; PIRCHE itd). Programi se zasnivaju 


\section{Nepodudarni antigen HLA davatelja: HLA-A32}

A32

LAtipizacija primatelja

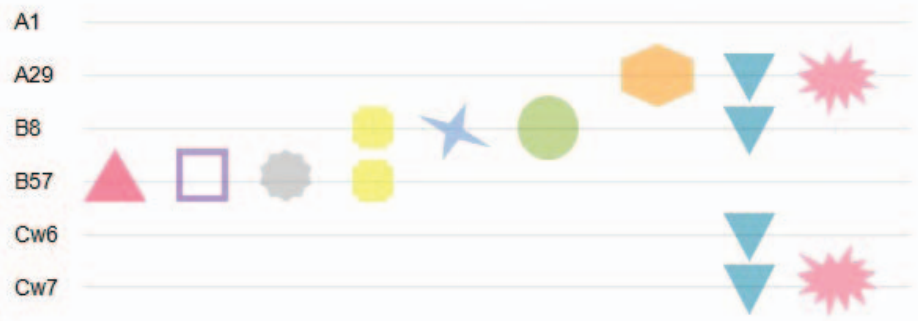

Slika 6. Određivanje podudarnosti na razini epitopa. HLA-A32 je nepodudarni antigen potencijalnog davatelja, međutim, analizom epitopa vidljivo je da primatelj ima sve epitope nepodudarnog antigena te njegov imunosni sustav neće prepoznati HLA-A32 kao stranu molekulu prema kojoj će razviti protutijela $^{24}$
Prvi uspješno transplantirani organ je bubreg te veliki dio spoznaja o učinku protutijela HLA na presađeni organ proizlazi upravo iz desetljeća laboratorijske i kliničke prakse transplantacije bubrega $^{11}$. Razvoj imunosupresivne terapije omogućio je liječenje stanične reakcije odbacivanja presatka, međutim, malo je postignuto u kontroli reakcije odbacivanja bubrega posredovanoj protutijeli$\mathrm{ma}^{27}$, stoga je razvoj tehnika čvrste faze, pogotovo Luminexa, značio ne samo tehnološki napredak, već je omogućio i stjecanje novih spoznaja o važnosti i ulozi protutijela HLA u reakciji odbacivanja presatka. Ipak, uz velike prednosti, ove metode imaju i svoja ograničenja zbog kojih je optimalne rezultate testiranja potrebno interpretirati u kombinaciji s drugom metodom, poput CDC-a, uz neophodnu usku suradnju djelatnika laboratorija za tipizaciju tkiva i kliničara.

Izjava o sukobu interesa: Autori izjavljuju da ne postoji sukob interesa.

\section{LITERATURA}

dinstveni skup epitopa, premda oni mogu biti prisutni i na više antigena različitih specifičnosti22. Ako primatelj i davatelj dijele iste epitope, neće doći do stvaranja protutijela HLA, što je osnova određivanja podudarnosti na razini epitopa (engl. HLA epitope matching) (slika 6) ${ }^{23}$.

Prednost ovakvih programa je veći izbor davatelja i bolji ishod transplantacije imuniziranih pacijenata, pa je HLA Matchmaker uveden i u Acceptable Mismatch program Eurotransplanta ${ }^{22,23}$. S druge strane, korištenje ovakvih programa zahtijeva izvođenje proširene tipizacije i primatelja i davatelja organa na razini visoke rezolucije, što predstavlja dodatno vremensko i financijsko opterećenje, naročito kod kadaveričnih transplantacija. Danas postoji još nekoliko izazova kako bi se HLA epitope matching uključio u programe alokacije organa. Potrebno je u potpunosti definirati epitope svih antigena HLA, te utvrditi njihov biološki značaj i imunogeničnost ${ }^{25,26}$.

Brojne studije povezale su stvaranje DSA, posebice de-novo DSA, s povišenim rizikom razvoja reakcije odbacivanja presatka posredovane protutijelima $^{17}$. Zahvaljujući visokoj osjetljivosti, testiranje seruma Luminex tehnikom postalo je nezaobilaznim dijelom poslijetransplantacijskog praćenja protutijela HLA.
1. Roelen DL, Doxiadis II, Claas FH. Detection and clinical relevance of donor specific HLA antibodies: a matter of debate. Transpl Int. 2012;25:604-10.

2. Lopes D, Barra T, Malheiro J, Tafulo S, Martins L, Almeida $M$ et al. Effect of Different Sensitization Events on HLA Alloimmunization in Kidney Transplantation Candidates. Transplant Proc. 2015;47:894-7.

3. Morales-Buenrostro LE, Terasaki PI, Marino-Vázquez LA, Lee JH, El-Awar N, Alberú J. Natural” human leukocyte antigen antibodies found in nonalloimmunized healthy males. Transplantation. 2008;86:1111-5.

4. Hirata AA, McIntire FC, Terasaki PI, Mittal KK. Cross reactions between human transplantation antigens and bacterial lipopolysaccharides. Transplantation. 1973;15:441-5.

5. El Aggan HA, Sidkey F, El Gezery DA, Ghoneim E. Circulating anti-HLA antibodies in patients with chronic hepatitis C: relation to disease activity. Egypt J Immunol. 2004; 11:71-9.

6. Locke JE, Zachary AA, Warren DS, Segev DL, Houp JA, Montgomery RA et al. Proinflammatory events are associated with significant increases in breadth and strength of HLA-specific antibody. Am J Transplant. 2009;9:21369.

7. Yabu JM, Anderson MW, Kim D, Bradbury BD, Lou CD, Petersen J et al. Sensitization from transfusion in patients awaiting primary kidney transplant. Nephrol Dial Transplant. 2013;28:2908-18.

8. Katerinis I, Hadaya K, Duquesnoy R, Ferrari-Lacraz S, Meier S, van Delden C et al. De novo anti-HLA antibody after pandemic H1N1 and seasonal influenza immunization in kidney transplant recipients. Am J Transplant. 2011;11:1727-33.

9. Terasaki PI, McClelland JD. Microdroplet assay of human serum cytotoxins. Nature. 1964;204:998-1000. 
10. Konvalinka A, Tinckam K. Utility of HLA Antibody Testing in Kidney Transplantation. J Am Soc Nephrol. 2015;26: 1489-502.

11. Tait BD. Detection of HLA Antibodies in Organ Transplant Recipients - Triumphs and Challenges of Solid Phase Bead Assay. Front.Immunol. 2016;7:570.

12. Patel R, Terasaki PI. Significance of the positive crossmatch test in kidney transplantation. N Engl J Med. 1969;280:735-9.

13. Garavoy MR, Rheinschmidt MA, Bogos M. Flow cytometry analysis: a high technology crossmatch technique facilitating transplantation. Transplant Proc. 1983;15:1939-94.

14. Buelow R, Mercier I, Glanville L, Regan J, Ellingson L, Janda $\mathrm{G}$ et al. Detection of panel-reactive anti-HLA class I antibodies by enzyme-linked immunosorbent assay or lymphocytotoxicity. Results of a blinded, controlled multicenter study. Hum Immunol. 1995;44:1-11.

15. Rački $S$, Bašić-Jukić $N$, Kes $P$, Sabljar-Matovinović $M$, Ratković-Gusić Iva, Bušić $M$ et al. Nacionalne smjernice za obradu i odabir primatelja i darivatelja bubrega usklađene sa smjernicama 2013. ERBP guideline on the management and evaluation of the kidney donor and recipient. $2^{\text {nd }}$ edition. Zagreb: Ministarstvo zdravlja Republike Hrvatske, 2016.

16. Tait BD, Hudson F, Cantwell L, Brewin G, Holdsworth R, Bennett $G$, i sur. Review article: Luminex technology for HLA antibody detection in organ transplantation. Nephrology (Carlton). 2009;14:247-54.

17. Lachmann N, Todorova K, Schulze H, Schönemann C. Luminex $\left({ }^{\oplus}\right)$ and its applications for solid organ transplantation, hematopoietic stem cell transplantation, and transfusion. Transfus Med Hemother. 2013;40:182-9.

18. Lachmann N, Todorova K, Schulze H, Schönemann C. Systematic comparison of four cell- and Luminex-based methods for assessment of complement-activating HLA antibodies. Transplantation. 2013;95:694-700.

19. Žunec R. Imunobiologija transplantacije. In: Bašić Jukić N, Kaštelan Ž (eds). Transplantacija bubrega. Zagreb: Medicinska naklada,2016;35-53.

20. Bettinotti MP, Zachary AA, Leffell MS. Clinically relevant interpretation of solid phase assays for HLA antibody. Curr Opin Organ Transplant. 2016;21:453-8.

21. Süsal C, Morath C. Virtual PRA replaces traditional PRA: small change but significantly more justice for sensitized patients. Transpl Int. 2015;28:708-9.

22. Heidt $\mathrm{S}$, Haasnoot GW, Claas FHJ. How the definition of acceptable antigens and epitope analysis can facilitate transplantation of highly sensitized patients with excellent long-term graft survival. Curr Opin Organ Transplant. 2018;23:493-9.

23. Duquesnoy RJ. Should epitope-based HLA compatibility be used in the kidney allocation system? Hum Immunol. 2017;78:24-9.

24. El-Awar N, Terasaki PI, Nguyen A, Sasaki N, Morales-Buenrostro LE, Saji $\mathrm{H}$ et al. Epitopes of human leukocyte antigen class I antibodies found in sera of normal healthy males and cord blood. Hum Immunol. 2009;70:844-53.

25. Cecka JM, Reed EF, Zachary AA. HLA high-resolution typing for sensitized patients: a solution in search of a problem? Am J Transplant 2015;15:855-6.

26. Sypek M, Kausman J, Holt S, Hughes P. HLA Epitope Matching in Kidney Transplantation: An Overview for the General Nephrologist. Am J Kidney Dis. 2018;71:720-31.

27. Wan SS, Ying TD, Wyburn K, Roberts DM, Wyld M, Chadban SJ. The Treatment of Antibody-Mediated Rejection in Kidney Transplantation: An Updated Systematic Review and Meta-Analysis. Transplantation. 2018;102:55768. 